\title{
Canine sporotrichosis: report of 15 advanced $\operatorname{cases}^{\mathbf{1}}$
}

\author{
Mariana B. Mascarenhas ${ }^{2 *}$, Natália L. Lopes ${ }^{2}$, Thiago G. Pinto ${ }^{3}$, Thiago S. Costa ${ }^{2}$, \\ André P. Peixoto ${ }^{3}$, Regina R. Ramadinha ${ }^{4}$ and Júlio I. Fernandes ${ }^{4}$
}

\begin{abstract}
Mascarenhas M.B., Lopes N.L., Pinto T.G., Costa T.S., Peixoto A.P., Ramadinha R.R. \& Fernandes J.I. 2018. Canine sporotrichosis: report of 15 advanced cases. Pesquisa Veterinária Brasileira 38(3):477-481. Programa de Pós-Graduação em Medicina Veterinária, Universidade Federal Rural do Rio de Janeiro, Seropédica, RJ 23890-000, Brazil. E-mail: mm.bezerra@yahoo.com

Sporotrichosis is a chronic, granulomatous and usually lymphocutaneous infection of animals and humans, caused by a dimorphic fungus, Sporothrix schenckii complex. The disease in dogs is considered rare, however, in the last years a crescent registration of cases was observed in Brazil, especially in the city of Rio de Janeiro. Fifteen dogs with ulcerated cutaneous lesions were seen at the Dermatology Service in the Small Animal's Hospital at Universidade Federal Rural do Rio de Janeiro, between January 2014 and October 2015. Most lesions were located on the head, mainly the nose. Lesions were even seen on the chest, disseminated on the body and on the limbs. Three dogs (20\%) exhibited the cutaneous-lymphatic form, with lesions initially on the distal aspect of one leg and ascending via lymphatics up the leg to the trunk and head. It was not ruled out the disseminated form in at least 3 dogs (20\%). They had consistent signs of generalized or disseminated disease exhibiting respiratory symptoms (nasal discharge, sneezing, stertorous breathing), anorexia and weight loss. Draining tracts and cellulitis were very common. Some had large areas of skin necrosis with exposure of muscle and bone. Definitive diagnosis was obtained by cytological examination of exudates, histological examination, and/or isolation of S. schenckii complex by fungal culture. Because of the severity of the lesions that mimic other disorders like neoplasms or autoimmune skin diseases, and due to the difficulties of getting an accurate diagnosis, this study describes 15 advanced cases of canine sporotrichosis.
\end{abstract}

INDEX TERMS: Canine sporotrichosis, Sporothrix schenckii, skin, dogs, ulcerations, levedurosis, zoonoses, mycoses.

RESUMO.- [Esporotricose canina: descrição de 15 casos avançados.] A esporitricose é uma doença infecciosa crônica, granulomatosa e frequentemente linfocutânea, causada por um fungo dimórfico do Complexo Sporothrix schenckii. A doença em cães é considerada rara, no entanto, nos últimos anos, um número crescente de casos foi registrado no Brasil, especialmente no Rio de Janeiro. Quinze cães com lesões

\footnotetext{
${ }^{1}$ Received on January 27, 2016.

Accepted for publication on June 2, 2017.

2 Programa de Pós-Graduação em Medicina Veterinária, Universidade Federal Rural do Rio de Janeiro (UFRRJ), Seropédica, RJ 23890-000, Brazil. *Corresponding author: mm.bezerra@yahoo.com

${ }^{3}$ Programa de Residência em Área Profissional da Saúde, Medicina Veterinária.

${ }^{4}$ Departamento de Medicina e Cirurgia Veterinária, Instituto de Veterinária, Universidade Federal Rural do Rio de Janeiro, Seropédica, RJ 23890-000, Brazil.
}

cutâneas ulceradas foram atendidos no Setor de Dermatologia do Hospital Veterinário de Pequenos Animais da Universidade Federal Rural do Rio de Janeiro, entre Janeiro de 2014 e Outubro de 2015. Todos os animais foram submetidos ao exame clínico e dermatológico. A maioria das lesões estava localizada na cabeça, principalmente no plano nasal. Havia também lesões no tórax, disseminada pelo corpo e nos membros. Três cães (20\%) apresentaram a forma cutâneo-linfática, com lesões inicialmente nos membros e se propagavam via vasos linfáticos para o tronco e a cabeça. Não foi descartada a forma disseminada em pelo menos 3 cães (20\%). Estes cães apresentaram sinais consistentes de doença generalizada ou disseminada, exibindo sinais respiratórios (descarga nasal, espirros, estertoração), anorexia e perda de peso. Fístulas e celulite eram muito comuns. Alguns tinham grandes áreas de necrose que desencadearam a exposição de músculo e osso. 0 diagnóstico definitivo da infecção foi obtido por 
exame citológico de exsudato e por exame histológico, e/ou apenas isolamento do complexo $S$. schenckii pela cultura de fungos. Por causa da severidade das lesões que imitam outras enfermidades, principalmente neoplasias e doenças autoimunes, e pela dificuldade de se obter o diagnóstico correto, este estudo descreve 15 casos avançados de esporotricose canina.

TERMOS DE INDEXAÇÃO: Esporotricose canina, Sporothrix schenckii, pele, caninos, ulcerações, levedurose, zoonose, micoses.

\section{INTRODUCTION}

Sporotrichosis is a cutaneous mycosis caused by a dimorphic fungus Sporothrix schenckii complex, which is widely distributed in nature (Rippon 1988). Molecular phylogenetic analyses have shown that several species exist within the $S$. schenckii species complex (Marimon et al. 2006, 2007, Madrid et al. 2010, Criseo \& Romeo 2010). The most common presentation of sporotrichosis in animals and humans is a chronic granulomatous lymphocutaneous infection that can spread due to immunodepression (Rosser \& Dunstan 2006, Cafarchia et al. 2007). In dogs and cats, three distinct presentations are recognized: the localized or fixed cutaneous form, the cutaneous-lymphatic and the disseminated form.

The cutaneous form of canine sporotrichosis is the most commonly reported. Multiple firm nodules, ulcerated plaques with raised borders or annular crusted and alopecic area are present, especially on the head, pinnae and trunk (Scott et al. 2001). The cutaneous-lymphatic form involves the skin, subcutaneous tissues and lymphatics. The disseminated form usually occurs as an uncommon sequel to the cutaneous-lymphatic form. In these cases, the liver and lungs are the primary sites of dissemination. The spleen, kidneys, eyes, central nervous system, gastrointestinal tract and mammary gland also have been reported as sites of dissemination (Rosser \& Dunstan 2006, Crothers et al. 2009). The main differential diagnosis is the American tegumentary leishmaniosis (Santos et al. 2007), infections granulomas and neoplasms (Scott et al. 2001).

Definitive diagnosis of infection is based on cytological examination of exudates, histopathology, or isolation of $S$. schenckii complex by fungal culture. As the fungal elements are rarely found in dogs, the diagnosis of canine sporotrichosis is often challenging (Cafarchia et al. 2007). The aim of the present study is to report 15 advanced cases of canine sporotrichosis. Diagnosis becomes more difficult since they mimic others important diseases like neoplasm and autoimmune skin diseases.

\section{MATERIALS AND METHODS}

Fifteen dogs with ulcerated cutaneous lesions were seen at the Dermatology Service in the Small Animal's Hospital from the Universidade Federal Rural do Rio de Janeiro, Brazil, between January of 2014 and October of 2015. All the dogs were submitted to clinical and dermatological examination. Definitive diagnosis of infection was active on either cytological examination of exudates, histological examination of a biopsy specimen, and or isolation of Sporothrix schenckii by fungal culture. Cytological examination was performed in all the animals at the time of examination using Romanowsky stains. Histopathological analysis with hematoxylin-eosin (HE) and periodic acid Schiff (PAS) was performed in 10 cases and fungal culture was carried out in 15 animals. For histopathological analysis and tissue culture, incisional biopsies were obtained from active lesions with $8 \mathrm{~mm}$ punch after asepsis and local anesthesia with $2 \%$ lidocaine. For fungal culture sterile swabs of exudates specimens and tissue fragments was taken for isolation of $S$. schenckii.

\section{RESULTS}

The diagnosis of sporotrichosis by cytological examination was getting in only 1 animal (6,6\%). Histopathological analysis revealed inflammatory infiltrate characterized by macrophages, neutrophils, some lymphocytes and plasma cells; rare fungal elements were seen in the cytoplasm of macrophages, which were evidenciated by PAS staining in 4 out of 10 cases $(0 \%)$. Fungal culture was positive in 15 out of 15 animals tested (100\%) (Table 1). Predominant cutaneous lesions (11 dogs, 73.3\%) were multiple ulcers, sometimes covered with exudates and crusts (Fig.1-3). Nodules with or

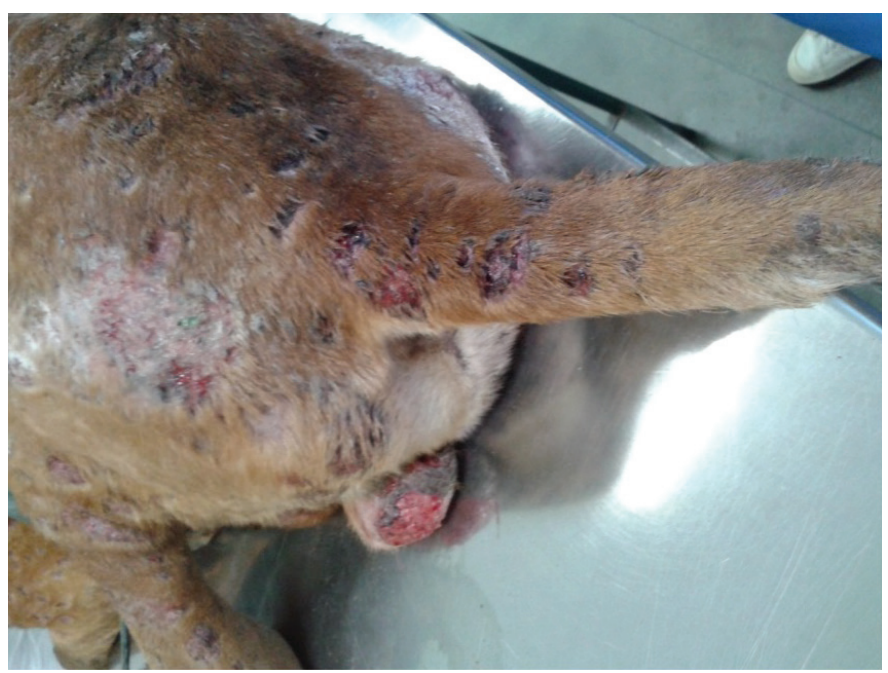

Fig.1. Generalized cutaneous ulcers and crust (case 1). The dog was diagnosed with hemoparasite, and it may have helped the spread of the infection because of immunodepression.

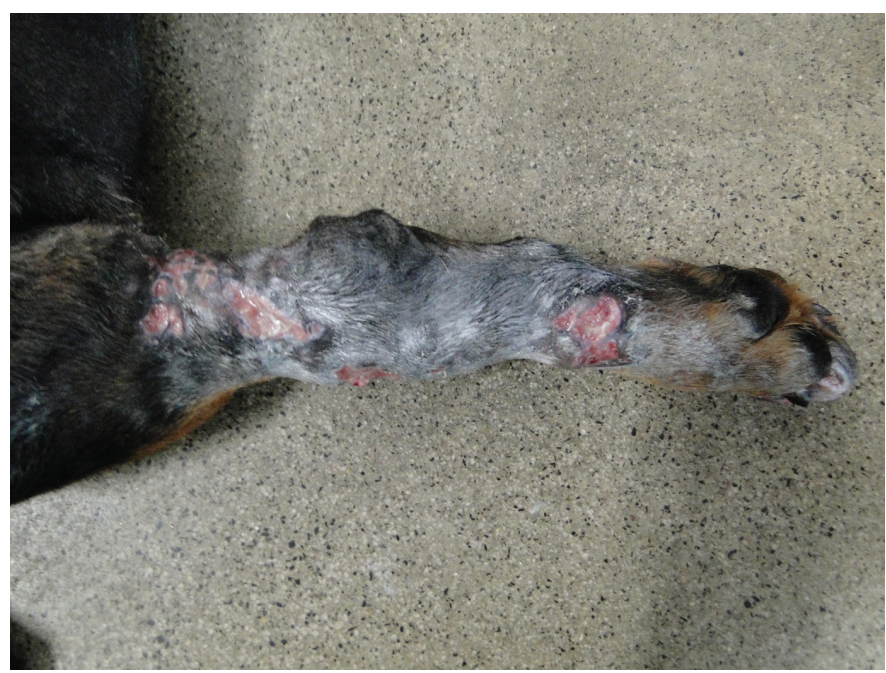

Fig.2. Nodular and ulcerated lymphangitis on the hind limbs (case 6). 
Table 1. Signalment, clinical signs and how the diagnosis was performed in $\mathbf{1 5}$ dogs attended at the Dermatology Service of Universidade Federal Rural do Rio de Janeiro

\begin{tabular}{|c|c|c|c|c|c|c|c|c|}
\hline Case & Breed & Age & Sex & Clinical signs & Location & Cytology & Histopathology & $\begin{array}{l}\text { Fungal } \\
\text { culture }\end{array}$ \\
\hline 2 & Poodle & 5 & $\mathrm{~F}$ & Ulcerated and crusted lesion & $\begin{array}{l}\text { Dorsal region and abdominal } \\
\text { area }\end{array}$ & Negative & Negative & Positive \\
\hline 3 & Fox Terrier & 2 & M & Ulcerated lesion and nodule & $\begin{array}{l}\text { Bridge of the nose and dorsal } \\
\text { region }\end{array}$ & Negative & Negative & Positive \\
\hline 4 & Poodle & 12 & M & Nodule, sneezing, nasal discharge & Bridge of the nose & Negative & Negative & Positive \\
\hline 6 & Rottweiller & 10 & M & Ulcerated and crusted lesions & Forelimbs & Negative & Not done & Positive \\
\hline 7 & Crossbred dog & 1 & M & Ulcerated and crusted lesions & $\begin{array}{l}\text { Nasal planum, forelimbs, } \\
\text { inguinal area }\end{array}$ & Negative & Not done & Positive \\
\hline 8 & Poodle & 12 & M & Ulcerated lesions and nodules & Dorsal region and inguinal area & Negative & Negative & Positive \\
\hline 9 & Chow-Chow & 4 & $\mathrm{~F}$ & Crusted lesions & Dorsal region and trunk & Negative & Not done & Positive \\
\hline 10 & Crossbred dog & 5 & $\mathrm{~F}$ & Nodular lesion and nasal discharge & Nasal planum & Negative & Negative & Positive \\
\hline 13 & Pinscher & 9 & $\mathrm{~F}$ & Nodular ulcerated lesions & Trunk & Negative & Positive & Positive \\
\hline 14 & Pitbull & 9 & $\mathrm{~F}$ & $\begin{array}{l}\text { Ulcers and crusts, nasal discharge, } \\
\text { draining tracts and cellulitis }\end{array}$ & $\begin{array}{l}\text { Generalized skin lesions, oral, } \\
\text { nasal and ocular lesions }\end{array}$ & Negative & Positive & Positive \\
\hline 15 & Crossbred dog & 10 & M & Ulcerated and crusted lesions & Generalized skin lesions & Negative & Positive & Positive \\
\hline
\end{tabular}

$\overline{\mathrm{M}}=$ male, $\mathrm{F}=$ female, Age $=$ years .

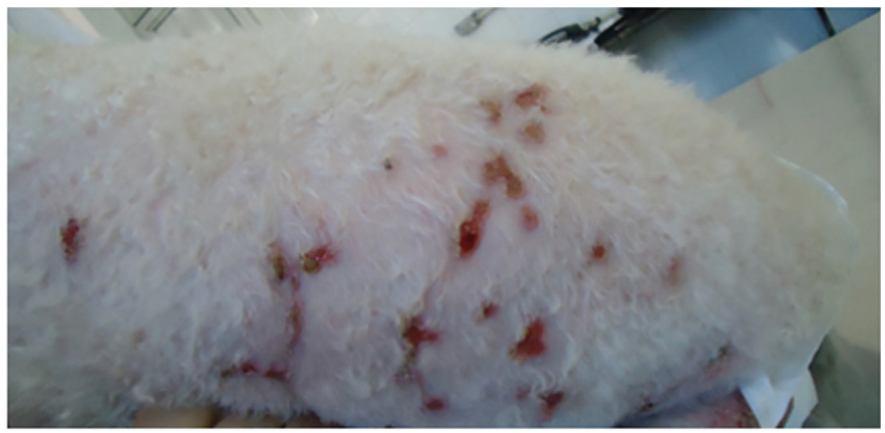

Fig. 3. Draining tracts and cellulitis disseminated on the body (case 2).

not draining tracts were seen in 5 dogs (33.3\%). Most lesions were located on the head, mainly the nose (7 dogs, $46.6 \%$ ) (Fig.4). Lesions were even seen on the chest (5 dogs) (Fig.3), disseminated on the body ( 3 dogs) and on the limbs ( 2 dogs) (Fig.2). Respiratory signs such as sneezing, nasal discharge and dyspnea were observed in 4 dogs $(26.6 \%)$. The lesions were most on the nose and sometimes extensive deformations (Fig.4). Three dogs (20\%) (case 6, 7 and 14) exhibited the cutaneous-lymphatic form, with lesions initially on the distal aspect of one leg and ascending via lymphatics up the leg to the trunk and head. It was not ruled out the disseminated form in at least 3 dogs (20\%) (case 1, 14 and 15). They had signs consistent with generalized or disseminated disease exhibiting respiratory signs (nasal discharge, sneezing, stertorous breathing), anorexia and weight loss. One dog (case 14) showed ocular involvement.

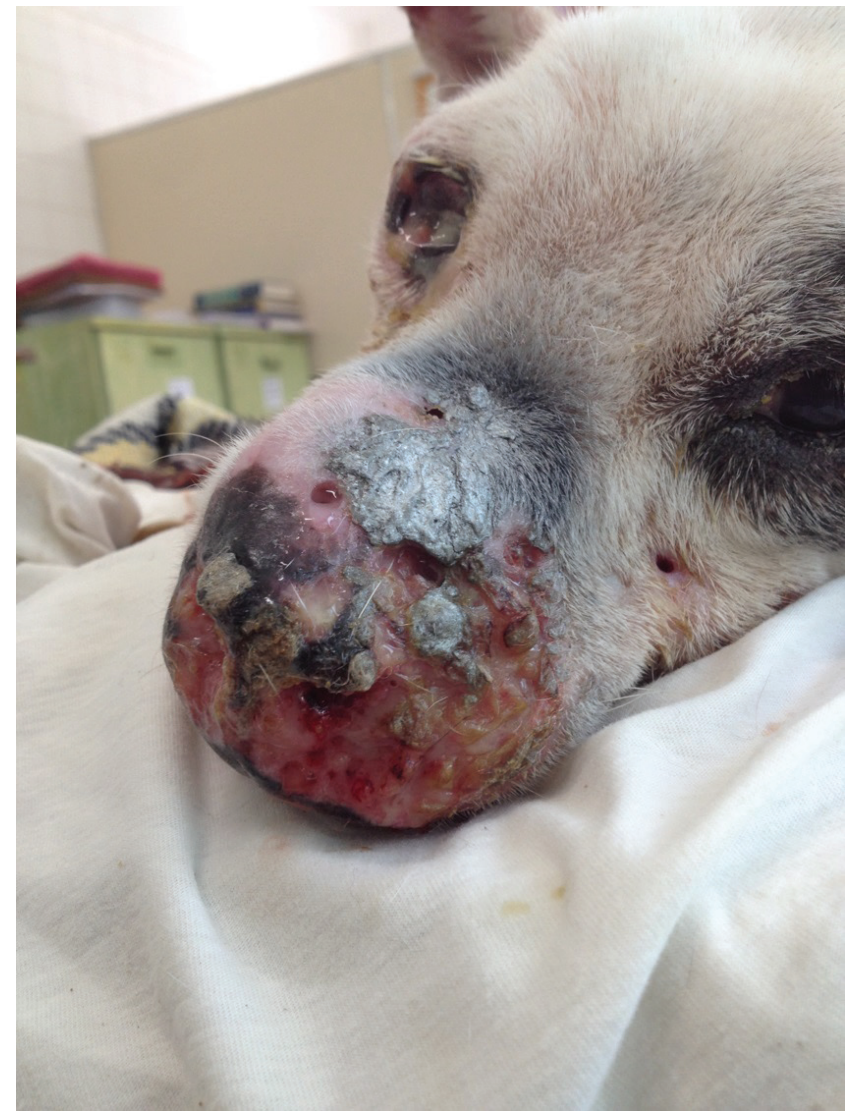

Fig.4. Dog (case 14) with generalized cutaneous ulcers, nasal and ocular involvement, exhibiting respiratory signs (nasal discharge, sneezing, stertorous breathing), anorexia and weight loss; signs consistent with disseminated disease. 


\section{DISCUSSION}

Canine sporotrichosis is considered a rare disease, with isolated cases being reported in the literature (Miranda et al. 2009). However, the zoonosis service of IPEC-Fiocruz has been observing a growing number of cases in Rio de Janeiro (Schubach et al. 2004). Schubach et al. (2006) described 44 cases of canine sporotrichosis between 1998 and 2003; however the authors suggest that the number of cases may actually be an underestimate due in part to the fact that the study was performed in a zoonosis service (IPEC, Fiocruz) and it does not represent the reality of clinical cases. In the present study, the exact casuistic of a Veterinary Dermatology Service in a period of 20 months is described, and as already observed, the number of cases is growing. The predominant findings in dogs with sporotrichosis were cutaneous ulcers located on the head, especially nose (Schubach \& Schubach 2000, Schubach et al. 2006).

It is likely that the habit of dogs to sniff their environment is related to acquisition of the fungus through the nose (Schubach et al. 2006). Most of the dogs initially presented with ulcerated areas, draining purulent exudates and crusted nodules. Draining tracts and cellulitis disseminated on the body were very common. Some dogs had large areas of necrosis with exposure of muscles and bone. The cutaneous-lymphatic form of sporotrichosis is considered uncommon (Scott et al. 2001); nonetheless the percentage of dogs diagnosed with this form was higher than those already reported (Schubach et al. 2006). Although considered extremely rare (Schubach \& Schubach 2000) three dogs had signs consistent with disseminated disease, exhibiting respiratory signs (nasal discharge, sneezing, stertorous breathing), anorexia and weight loss. All these clinical signs, including the localized form, presented a more aggressive and widespread pattern than the forms described in the literature at the time of the first appointment. These advanced clinical findings might be associated to immunosuppression and lack of diagnosis.

The large number of dogs with sporotrichosis observed in this epidemic might be attributed to cats acting as the main source of infection (Schubach \& Schubach 2000, Schubach et al. 2006), as seven dogs of this study had contact with cats with sporotrichosis. One dog diagnosed with hemoparasite, presented an uncommon large number of organisms in the cytological examination. The hemoparasite may have improved the spread of the infection because of immunodepression (Rosser \& Dunstan 2006, Cafarchia et al. 2007). Most nodular lesions on the nose or sometimes extensive deformations on the face must be differentiated from carcinomas or other neoplasias (Scott et al. 2001).

Diagnosis usually requires tissue culture, as dogs typically harbor very few organisms (Moriello et al. 1988, Werner \& Werner 1994); therefore for the accurate diagnosis we performed biopsy for tissue culture and for histopathological examination. On histopathology, granulomatous dermatitis was the most common finding. Although, the clinical features resembled the typical sporothricosis in cats (ulcerated areas, draining purulent exudates, crusted nodules and draining tracts), on histopathology it didn't occur because dogs still harbor very few organisms. For the definitive diagnosis we strongly recommend histopathology examination to rule out autoimmune skin disorders and neoplasias. In addition, the tissue culture must be performed. It is very important to establish the diagnosis as immunosuppressive drugs are contraindicated in patients with sporotrichosis (Moriello et al. 1988). Thus far, we alert veterinarians to the increased number of canine sporotrichosis, therefore, this disease should be considered as a possible differential diagnosis in dogs with ulcerative and nodular skin disorders. In addition, because of the zoonotic potential of this disease and the dog-human proximity and interaction, sporothricosis must be properly diagnosed and treated.

Acknowledgements.- The authors are grateful to the Coordenação de Aperfeiçoamento de Pessoal de Nível Superior (CAPES) and to the Conselho Nacional de Desenvolvimento Científico e Tecnológico (CNPq).

\section{REFERENCES}

Cafarchia C., Sasanelli M., Lia R.P., Caprariis D., Guillot J. \& Otranto D. 2007. Lymphocutaneous and nasal sporotrichosis in a dog from southern Italy: case report. Mycopathologia 163(2):75-79. http://dx.doi.org/10.1007/ s11046-006-0086-x. PMid:17294354.

Criseo G. \& Romeo 0. 2010. Ribosomal DNA sequencing and phylogenetic analysis of environmental Sporothrix schenckii strains: comparison with clinical isolates. Mycopathologia 169(5):351-358. http://dx.doi.org/10.1007/ s11046-010-9274-9. PMid:20119849.

Crothers S.L., White S.D., Ihrke P.J. \& Affolter V.K. 2009. Sporotrichosis: a retrospective evaluation of 23 cases seen in northern California (19872007). Vet. Dermatol. 20(4):249-259. http://dx.doi.org/10.1111/j.13653164.2009.00763.x. PMid:19659536.

Madrid H., Gené J., Cano J., Silvera C. \& Guarro J. 2010. Sporothrix brunneoviolacea and Sporothrix dimorphospora, two new members of the Ophiostoma stenoceras-Sporothrix schenckii complex. Mycologia 102(5):1193-1203. http://dx.doi.org/10.3852/09-320. PMid:20943519.

Marimon R., Cano J., Gené J., Sutton D.A., Kawasaki M. \& Guarro J. 2007. Sporothrix brasiliensis, S. globosa, and S. mexicana, three new Sporothrix species of clinical interest. J. Clin. Microbiol. 45(10):3198-3206. http:// dx.doi.org/10.1128/JCM.00808-07. PMid:17687013.

Marimon R., Gené J., Cano J., Trilles L., Lazéra M.S. \& Guarro J. 2006. Molecular phylogeny of Sporothrix schenckii. J. Clin. Microbiol. 44(9):3251-3256. http://dx.doi.org/10.1128/JCM.00081-06. PMid:16954256.

Miranda L.H.M., Quintella L.P., Santos I.B., Menezes R.C., Figueiredo F.B., Gremião I.D.F., Okamoto T., Oliveira R.V.C., Pereira S.A., Tortelly R. \& Schubach T.M.P. 2009. Histopathology of canine sporotrichosis: a morphological study of 86 cases from Rio de Janeiro (2001-2007). Mycopathologia 168(2):79-87. http://dx.doi.org/10.1007/s11046-009-9198-4. PMid:19360480.

Moriello K.A., Franks P., Delany-Lewis D. \& King R. 1988. Cutaneous-lymphatic and nasal sporotrichosis in a dog. J. Am. Anim. Hosp. Assoc. 24:621-626.

Rippon J. 1988. Sporotrichosis, p.325-352. In: Ibid. (Ed.), Medical Mycology: the pathogenic fungi and pathogenic actinomycetes. 2nd ed. W.B. Saunders Co., Philadelphia

Rosser Jr E.J. \& Dunstan R.W. 2006. Sporotrichosis, p.608-612. In: Green C.E. (Ed.), Infectious Disease in Dog and Cat, Saunders Elsevier, St Louis, Missouri.

Santos I.B., Schubach T.M., Leme L.R., Okamoto T., Figueiredo F.B., Pereira S.A., Quintella L.P., Madeira M.F., Coelho F.S., Reis R. \& Schubach A.O. 2007. Sporotrichosis, the main differential diagnosis with tegumentary leishmaniosis in dogs from Rio de Janeiro, Brazil. Vet. Parasitol. 143(1):1-6. http://dx.doi.org/10.1016/j.vetpar.2006.08.002. PMid:16973286.

Schubach T.M.P. \& Schubach A.O. 2000. Esporotricose em gatos e cães: uma revisão. Clin. Vet. 29:21-24. 
Schubach T.M.P., Schubach A., Okamoto T., Barros M.B., Figueiredo F.B., Cuzzi T., Fialho-Monteiro P.C., Reis R.S., Perez M.A. \& Wanke B. 2004. Evaluation of an epidemic of sporotrichosis in cats: 347 cases (1998-2001). J. Am. Vet. Med. Assoc. 224(10):1623-1629. http://dx.doi.org/10.2460/ javma.2004.224.1623. PMid:15154732.

Schubach T.M.P., Schubach A., Okamoto T., Barros M.B.L., Figueiredo F.B., Cuzzi T., Pereira S.A., Santos I.B., Paes R.A., Leme L.R.P. \& Wanke B. 2006. Canine sporotrichosis in Rio de Janeiro, Brazil: clinical presentation, laboratory diagnosis and therapeutic response in 44 cases (1998-2003).
Med. Mycol. 44(1):87-92. http://dx.doi.org/10.1080/13693780500148186. PMid:16805098.

Scott D.W., Miller W.H. \& Griffin C.E. 2001. Fungal skin diseases, p.386-390. In: Muller and Kirk's Small Animal Dermatology. 6th ed. W.B. Saunders, Philadelphia.

Werner A.H. \& Werner B.E. 1994. Sporotrichosis in man and animal. Int. J. Dermatol. 33(10):692-700. http://dx.doi.org/10.1111/j.1365-4362.1994. tb01512.x. PMid:8002136. 